\title{
Date Palm and Their Different Food Uses in Algeria's South-West Oases: Touat, Gourara and Tidikelt
}

\author{
Merzaia Blama Aicha ${ }^{1}$, Zaki Abdennebi ${ }^{2}$, Moussaoui Boudjemaa ${ }^{2}$, Babker Abdekader ${ }^{3}$ and Abakhti Abdekader ${ }^{4}$ \\ 1. Agri-food technologies Division. The National Institute of Agricultural Research of Algeria;2 rue les frères Ouaddek-BP N 200 \\ Hassen Badi -16200-EL-Harrach Algiers, Algeria \\ 2. Experimental Station of Adrar. The National Institute of Agricultural Research of Algeria; B.P 299, Ouled Aissa, Adrar \\ WilayaP.Box.01000 Algiers, Algeria \\ 3. ENS(EcoleNormaleSuperior),English Department,Bouzarhea;93, Rue Ali Remli, Bouzarhea P.O.Box. 16340Algiers, Algeria \\ 4. University of Biskra, Algeria, Department of Natural and Life Sciences, Faculty of Exact Sciences and Natural and Life Sciences, \\ University of Biskra, BP 145, 07000 Biskra, Algeria
}

\begin{abstract}
Dates are considered as the most important food in the south-west oases of Algeria. The Date Palm (Phoenix dactylifera) has known some kind of specificity in its different life phases, compared to all the rest of oases cultivate plants. It is thanks to that person could settle down. A study within a ministerial research project about the date palm variety in the previous areas has shown that there are 400 spices of dates. Thanks to this diversification types, members of this community were able to acquire experience in the field of the uses of date in their nutritional behaviour. Harvest begins from precocious summer's soft date variety in June, as in the late autumn variety in October. In addition, there are different type of the date: wet, semi-wet and dry date. For each variety, there is a particular method of its use. It is an example of sustainable food, is the one present in all oasis occasions. The aim of the current study was to examine the different methods of nutritional ate uses, in Touat, Gourara and Tidikelt, by its inhabitants, and to show the local skills sustained across the generations.
\end{abstract}

Key word: Dates varieties, uses, Touat, Gourara and Tidikelt, nutritional behavior, local skills.

\section{Introduction}

Date palm tree is the symbol of oasis in the southern region of Algeria. It has had great role and outstanding cultural value in people's lives, both as individuals and as a society. People get their food, even medicine from it. Most of all, it has entered even into people's social life. History has recorded it amongst of heritage civilization, which characterized TOUAT (Adrar) area-Tuat or Touat (Berber language, Tuwat) is a natural region of desert in central Algeria that contains a string of small oases [1]. It is included in our traditions and customs. Through this Ethnobotanical study, which

Corresponding author: Merzaia Blama Aicha, Ph.D. student, research fields: sociology, ethnobotanic, Agri-food development. touches all relationships between dates palm and human beings, the authors describe some of the different uses of dates, the local artisan and skills in this industry.

\section{Materials and Methods}

In order to get information for studying date's nutritional practises in the region (Touat, Gourara, Tidikelt), the authors have used the technique of participant observation, a questionnaire for data collection from the resource persons (man and woman), peasants the authors have interviewed, for this reason there has been visits to the fields of palms aimed at collecting information. Besides this, the present work was based on scientific research, litterateurs, statistic of the Ministry of Agriculture, Rural Development and Fisheries of Algeria. 


\section{Results and Discussions}

\subsection{The Area of Study}

Geographically, Adrar prolongs between longitudes $0^{\circ} 30^{\prime} \mathrm{E}$ and $0^{\circ} 30^{\prime} \mathrm{W}$, latitudes between $26^{\circ}$ and $28^{\circ} 30^{\prime} \mathrm{N}$, is known for their four major geographical areas:

(1) Gourara region: located municipalities’ units, which border the big marsh of Timimoune. These are Ksar Ouled Kadour, Ouled Said, Timimoune, Ouled Aissa, Talmin, Charwil, Mtarfa, Daldoul, and Ouaghrout. Its area is about 65,203 $\mathrm{km}^{2}$.

(2) Central Touat: It is composed of twelve municipalities, which are located along Messaoud valley. These are Tsabit, Esabaa, Buda, Adrar, Timi, Tametit, Fonoghil, Tamset, ZaouiaKouta, Inzegmir, Sali, and Regan.

(3) East South Region: Tidikelt that is composed of four municipalities: Aulef, Timoukten, Akebli and Tit. Its area is about $24,536 \mathrm{~km}^{2}$.

(4) West South Region: Tinzrouft, which is composed of two municipalities: Bordj Badji Mokhtar, and Timyawine. Its area is about $132,579 \mathrm{~km}^{2}$.

The region is crossed by many valleys: Imguden, which end at Gourara, the Messaud valley that ends at Touat, and Gurit valley, which ends at Tidikelt. Adrar is characterized with its seasonal winds such as sirocco, which is a hot wind known locally as 'Arifi'.

\subsubsection{Vegetation}

It is essentially composed of palms oasis (more than 24,980 hectares), under their microclimate grown the vegetables: market gardening, cereal crop, forage crop and some fruits such the pomegranate tree, the fig tree, vine, aromatic and medicinal plants cultivated mint, basil, fennel, fenugreek, cumin, rosemary, coriander, nigella etc., and the adventise plants.

The spontaneous plants are classified in relation to the types of land: such as sand, clay, or salt. In addition, they adapt to the nature of climate such: (Aristada pungens), (Retam retama), (Carnilaca moncatha), (Zygophyllum album), (Acacia raddiana),
(Tamarix sp), (Salsola foetida) etc..

- Surface Area: 439,700 km²

- Population: 432,193 in habitants in 2011.

- Land availability: a total agricultural area 366,463 ha, utilized agricultural area: 36,351 ha.

- Main natural resources: Natural gas, underground water, moreover, there is a huge amount of water in a layer that is close to the surface, particularly towards the axis of Adrar, Timimoune, and Regan, because there are the complex continental whose limits vary according to the regions and that one defines under the term of continental insert [2]. The system of exploitation of water resources in the oasis areas of Adrar is channel of irrigation, called the 'foggara' (1.400 'foggara' in activity). Thus, the 'foggara' is a group of interconnected wells, each with a basal surface relatively reduced from its predecessor. Is compound in total surface relatively tilted towards the tendency of the ground to allow water to gather and flow under the influence of gravity [3].

Animal Resource [4]: Bovine species 1,186 (in heads), ovine species 462,465 (in heads), caprine species 148,167 (in heads), camel species 49,950 (in heads).

\subsection{Nutritional Uses of Dates}

There is a strong relationship between man in the area and palm tree. Men take care of irrigating and providing its soil with organic fertilizer. They are different ways of attending to it. Palm tree, on its part, provides various kinds of date, which are exploited by men in different ways, such as for human nutrition as well as food for animals. In addition, tools invented since time immemorial is still in use.

With 2,744.090, date palm and according to the Ministry of Agriculture, Rural Development and Fisheries of Algeria Ministry of Agriculture, Rural Development and Fisheries of Algeria the estimated production of dates during the year 2014 was 907,278 quintals [4]. A research project has shown that there are 400 spices of date palm tree (NRP) (National 
Research Program) [5]. Harvest begins for precocious summer's soft date variety in June. As for the late autumn variety in October (Table 1), despite the disease 'Bayoud' (Fusarium oxysporum albedinis), the National Institute of Agricultural of Algeria Research at Adrar has a program to select and breed high quality resistant varieties of date palm, and has selected around 150 varieties for testing. All of the varieties in the collection have been characterized and currently one variety shows good potential for quality and disease resistance [6] especially the 'Taquerbuch' variety.

3.2.1 Different Phrases of Date Ripening in the Region

Palm tree inflorescence locally called 'Dokar'. Peasants start making the process of pollination of palm trees annually. Simultaneously, they start uttering some religious prayers and blessing such as "in the name of God" and "Peace upon the prophet Mohamed". Date palm pollen is used in the traditional medicine in this region to restore sexual potency and to cure male infertility [7], 'Dokkar' contains steroids, alkaloids and flavonoids through a multitude of central and peripheral means. Study suggests the potential utility in managing sexual dysfunction and indicates that this pollen can be used as a stimulator of sexual behavior and curing of male impotency (i.e. sexual arousal/erection disorders) and pre-mature ejaculation [7]. It is also used locally to stop bleeding.

After weeks of sterilization with Date palm pollen, first signs of fruits emerge.

Types of dates and its uses:

Given the sacred character of Palm dates in different religions, especially Islam, many researchers have been extensively studied in the different/various aspects, even at the present time, even at the present time. The importance of dates, primarily due to their nutritional value, as well as the benefits of her tree parts in various fields where the dates are the source of energy and vitality of the various members of the body, as it gives the per kilogram of it about 3,470 calories [8].

Dates contain estrone, estrogen, tannins, proanthocyanidins (OPC); piperidine derivatives, including pipecolic acid; and phytohormones. Phenolic compounds, mainly cinnamic acids, and flavonoids (flavones, flavonols, and flavanones).

Phytochemical screening yielded flavonoids, carbohydrates, and/or glycosides, sterols and/or triterpenes. In addition, other active constituents such as tannins, saponins, sterols and/or triterpenes, alkaloids and coumarins were present in date palm tissues (shoot tip, pollen grain, leaves, fruits, and callus [8].

(1) Soft date variety:

When date palm tree starting to bear fruit, the peasants become happier and they exchange this precocious type of dates as an expression of social values of exchange and cooperation. Their families consume from the dates crops and they preserve the rest or sell it in the market. [9].

Table 1 Some dates varieties and their uses in the Touat, Gourara and Tidikelt.

\begin{tabular}{|c|c|c|c|}
\hline Dates varieties & Preparation & Observation & Ingredients add \\
\hline 'Echekh m'hamed' & 'Btana'/'sfouf' & Precocious variety & \multirow{11}{*}{$\begin{array}{lll}\text { Dray cheese } & \text { powdered, } & \text { juniperus } \\
\text { communis, } & \text { Oscimum } & \text { basilicum, } \\
\text { Pennisetum } & \text { glaucum, } & \text { Rosmarius } \\
\text { officinalis } & & \end{array}$} \\
\hline 'Elferana' & 'Btana'/'sfouf' & Precocious variety & \\
\hline 'Ba makhlof' & 'Btana'/‘sfouf' & Precocious variety & \\
\hline 'El mesoudia' & 'Btana'/‘sfouf' & Precocious variety & \\
\hline 'Agas' & 'Btana'/'sfouf' & Precocious variety & \\
\hline 'Tigaza' & 'Btana'/'sfouf' & Precocious variety & \\
\hline 'Taqerbouche' & 'Btana'/'sfouf' & Precocious variety & \\
\hline 'Aremou' & 'Btana'/‘sfouf' & Later variety & \\
\hline 'Tinaser' & 'Btana'/'sfouf' & Later variety & \\
\hline 'Tademan' & 'Btana'/'sfouf' & Later variety & \\
\hline 'Achedakh' & 'Btana'/‘sfouf' & Later variety & \\
\hline
\end{tabular}


The prophets Mohamed (peace be upon him (PUBH)) had his breakfast, which consisted of dates before he prayed [10].

(2) Semi-dry of date/soft dry of date variety:

Many people of 'ksaurs' preserve it in a special manner in bags of cloth. They do that in the following manner: Good date is separated from the bad (like the one, which has shriveled up).

After the boiled water is poured on it so that to purify it and preserve it from rotting. It left for a while until it becomes soft.

Preparation of 'Btana': To make 'Btana' first of all dates cleaned up with fresh water to eliminate dust and other appeared dirty as the rest of insects and the bird excrement.

This step is repeated many times until enhancing soften dates. This operation was done in cleaned performed metallic container, sometimes the villagers use a hot water to soften dried date, then, and dates were amalgamated and mixed for accelerating it softness. In the end of this step, the authors obtain a paste of date which is usually piled up in a proper plastic bag, or in linen bag or very original into an old goatskin. The date paste is piled with layers, between each layer a small pressure is established, this aim to homogenate dates repartition and the second objective is to exclude the residual air from the bag. On each layer of this paste, it is dispersed a small amount of a grind mixture of aromatic dried plants as like as basil (Ocinum basilicum L.), juniper (Juniperus communis L.), rosemary (Rosmarius officinalis L.), wormwood (Artemisia Herba-Alba L.), the main role of this plants is to give an agreeable smell and taste to dates. After filling, the bag is attached and closed hermetically. A small exposure to the sun helps to perform the quality of the paste that takes a good consistence. The period of sun exposure varies with the temperature ( 2 days in winter, half-day in summer). The bag is periodically returned for exposing its two faces to the sun. Then the bag is stocked in a dry place and away from insects and the stock destructors. After one month of preservation, dates would be able for consumption "this period may take several months in some region depending to the habitant needs" [9].

The Date is preserved, thus for months and used when needed; for instance, when there is a shortage of date in the market or on feasts or other religious occasions such as Ramadan.

Varieties of dates suitable for this kind of preservation are 'Tilmsou', 'Tazerzait', 'Masoudia', 'Taqrbouchet', ‘Ahrtane'.

Some dishes such as 'Kaabouch', 'Rfis' are prepared by the use of the 'Btana'. They added to it 'Laklilla' dray cheese and millet (Pennisetum glaucum) grinded.

(3) Dry variety of date:

Uses of dry dates: Dry dates are purified and crashed, by using a rock (schist) and another smaller one (pebbles).

After that, perianth, and nuts are removed from dates. Next, a date is ground, in a big wooden pestle, after that it is blown through using a flat container made out of palm tree leaves. Then, remaining dust is removed, big particles of ground that separate from smaller ones. Finely, 'Sfouf', which is the name of the result of this process, is put in another container made also out of palm tree called 'Tadara'.

Millet (Pennisetum glaucum) flour and dry cheese are added to 'sfouf', which becomes ready to be consumed throughout the year without undergoing any kind of rotting. Small particles of 'Sfouf' are called 'Anghad'.

'Anghad': is the powder that obtained through grinding dates. It is given to babies as food, tranquilizer and something that gives them energy. 'Anghad' has been proven scientifically that it helps in the growth of children because it contains Phosphor, Calcium, which are important in building and strengthening bones and teeth [8]. The 'Anghad' also is used to prepare padding, and sauces of some popular local dishes such as bread of 'Kesra', bread of 'Redfa', and 'Mardouf'. 
'Azwa': is the remnant of dates, which is used as medicine for colic and a purifier of wounds. 'Marissa': it is a mixture of date and water given to the thirsty person in the desert.

\subsubsection{Honey of Dates:}

Some dates palm which be found in the in the fallow land, produced the honey that resembles the resin; the women collected these fallen honeys, for prepared herbal remedies for stomachache, in cases of colic and gases of babies. This honey is mixed, with the seeds of some herbal: (Cuminum cyminum L.) (Carumcarvi L.), (Nigella sativa L.). This recipe called 'kmouna'.

\section{Conclusions}

A date palm is a source of energy it is a first and the last food of people of the desert. For this importance and properties, the prophet Mohammed (PBUH) said: "A family which has dates will not be hungry." It is necessary to develop the system of conservation and given a specific important for all varieties of dates, for that the, Ministry of Agriculture, Rural Development and Fisheries of Algeria device support in agriculture, through establish a chain of dates. Consequently, the authors are able to benefit our ancient heritage.

\section{Acknowledgement}

The authors wish to express their gratitude to Professor Abdallah Kolli (ENS), Doctor Mohamed Saib Musette (CREAD), and Ahmed Bennia, for their scientific cooperation's, support and encouragement.

\section{References}

[1] Abedi, A., Karimian, S. M., Parviz, M., Mohammadi, P., and Roudsari, H. R. S. 2014. "Wikipedia, the free encyclopedi.” Effect of Aqueous.

[2] Atlas of environment. 2002. Albian Watertable, Ed.
Symbiose Communication Enverenement in Partenariat with Burlington Resources Alegria. 38.

[3] Merzaia, B. A., and Laaboudi, A. 2007. "The 'Foggara': The Possibility to Exploited.” Review of the Agronomic Research, No 20, the National Institute of Agricultural Research of Algeria 12: 90-8.

[4] Ministry of Agriculture, Rural Development and Fishing, Department of Statistics, Agricultural Statistics and Information Systems, Superficies and Production, Series b, December 2014.

[5] NRP (National Research Program). Project Cod: ARSAARM 21698: Project Title: Inventory, Characterization and Conservation Cultivates of Dates Palm in the Different Phoenicicole Zones of South-West of Adrar Area. The experimental Station of Adrar, The National Institute of Agricultural of Algeria (Zaki and all).

[6] UNDP (United Nations Development Programme)-GEF. 1998. Project of the Governments of Algeria, Morocco and Tunisia, Project Number: RAB/98/G31/A/1G/72, Project title: Participatory Management of Date Palm Plant, Genetic Resources in Oases of the Maghreb, (2001-2005), Maghreb Date Palm.

[7] Abedi, A., Karimian, S. M., Parviz, M., Mohammadi, P., and Roudsari, H. R. S. 2014. "Effect of Aqueous Extract of Phoenix Dactylifera Pollen on Dopamine System of Nucleus Accumbens in Male Rats Neuroscience \& Medicine.” 5: 49-59.

[8] Alrubaye, D. 2013. The Arabian Encyclopedia of Medicinal Herbs. Part-1 Food Elements, Dar ihya' al-Turath, Beirut, Lebanon, co-op Al-Ghadeer Printing Press, Iraq, Basrah. 2013.

[9] Merzaia, B. A., and Zaki, A. 2007. “An Ethnobotanical Study about Touat Region's Palms.” Review of Agronomic Research No 21, The National Institute of Agricultural of Algeria. 6: 58-48.

[10] Sahih Muslim, the Book of Drinks, Chapter: Storing Dates and other Provisions for one's Children, Hadith 210.

[11] Abekhti, A., 2015. Evaluation and Valorization of the Traditional Process of Conservation Dates "Btana” and Determining Its Microbial Biodiversity. Doctoral Thesis, Faculty of Natural Sciences and Life. Department of Biology, Laboratory of Applied Microbiology, Oran University. 